\title{
Early Pliocene vegetation and hydrology changes in western equatorial South America
}

\author{
Friederike Grimmer ${ }^{1}$, Lydie Dupont ${ }^{1}$, Frank Lamy ${ }^{2}$, Gerlinde Jung ${ }^{1}$, Catalina González ${ }^{3}$, and Gerold Wefer ${ }^{1}$ \\ ${ }^{1}$ MARUM - Center for Marine Environmental Sciences, University of Bremen, Leobener Str. 8, 28359 Bremen, Germany \\ ${ }^{2}$ Alfred-Wegener-Institute for Polar and Marine Research, Am Handelshafen 12, 27570 Bremerhaven, Germany \\ ${ }^{3}$ Department of Biological Sciences, Universidad de los Andes, Cra. 1 \#18a-12, Bogotá, Colombia
}

Correspondence: Friederike Grimmer (fgrimmer@marum.de)

Received: 2 October 2017 - Discussion started: 3 November 2017

Revised: 12 October 2018 - Accepted: 22 October 2018 - Published: 14 November 2018

\begin{abstract}
During the early Pliocene, two major tectonic events triggered a profound reorganization of ocean and atmospheric circulation in the eastern equatorial Pacific (EEP), in the Caribbean Sea, and on adjacent land masses: the progressive closure of the Central American Seaway (CAS) and the uplift of the Northern Andes. These affected, among other things, the mean latitudinal position of the Intertropical Convergence Zone (ITCZ). The direction of an ITCZ shift, however, is still debated, as numeric modeling results and paleoceanographic data indicate shifts in opposite directions. To provide new insights into this debate, an independent hydrological record of western equatorial South America was generated. Vegetation and climate of this area were reconstructed by pollen analysis of 46 samples from marine sediments of Ocean Drilling Program (ODP) Hole 1239A from the EEP comprising the interval between 4.7 and 4.2 Ma. The study site is sensitive to latitudinal ITCZ shifts insofar as a southward (northward) shift would result in increased (decreased) precipitation over Ecuador. The presented pollen record comprises representatives from five ecological groups: lowland rainforest, lower montane forest, upper montane forest, páramo, and broad range taxa. A broad tropical rainforest coverage persisted in the study area throughout the early Pliocene, without significant open vegetation beyond the páramo. Between 4.7 and $4.42 \mathrm{Ma}$, humidity increases, reaching its peak around 4.42 Ma and slightly decreasing again afterwards. The stable, permanently humid conditions are rather in agreement with paleoceanographic data, indicating a southward shift of the ITCZ, possibly in response to CAS closure. The presence of páramo vegetation indicates that the Ecuadorian Andes had already reached
\end{abstract}

considerable elevation by the early Pliocene. Future studies could extend the hydrological record of the region further back into the late Miocene to see if a more profound atmospheric response to tectonic changes occurred earlier.

\section{Introduction}

The progressive closure of the Central American Seaway (CAS) and the uplift of the Northern Andes profoundly reorganized early Pliocene ocean and atmospheric circulation in the eastern equatorial Pacific (EEP). The formation of the Isthmus of Panama, and especially the precise temporal constraints of the closure of the Panama Strait, have been the subject of numerous studies (Bartoli et al., 2005; Groeneveld et al., 2014; Hoorn and Flantua, 2015; Montes et al., 2015; Steph, 2005). A recent review based on geological, paleontological, and molecular records narrowed the formation sensu stricto down to $2.8 \mathrm{Ma}$ (O'Dea et al., 2016). Temporal constraints on the restriction of the surface water flow through the gateway were established by salinity reconstructions on both sides of the isthmus (Steph et al., 2006b, Fig. 1). The salinities first start to diverge around 4.5 Ma. A major step in the seaway closure between 4.7 and $4.2 \mathrm{Ma}$ was also assumed based on the comparison of mass accumulation rates of the carbonate sand fraction in the Caribbean Sea and the EEP (Haug and Tiedemann, 1998). The closure of the Central American Seaway has been associated with the development of the EEP cold tongue (EEP CT), strengthened upwelling in the EEP, the shoaling of the thermocline, and a mean latitudinal shift of the Intertropical Convergence Zone 


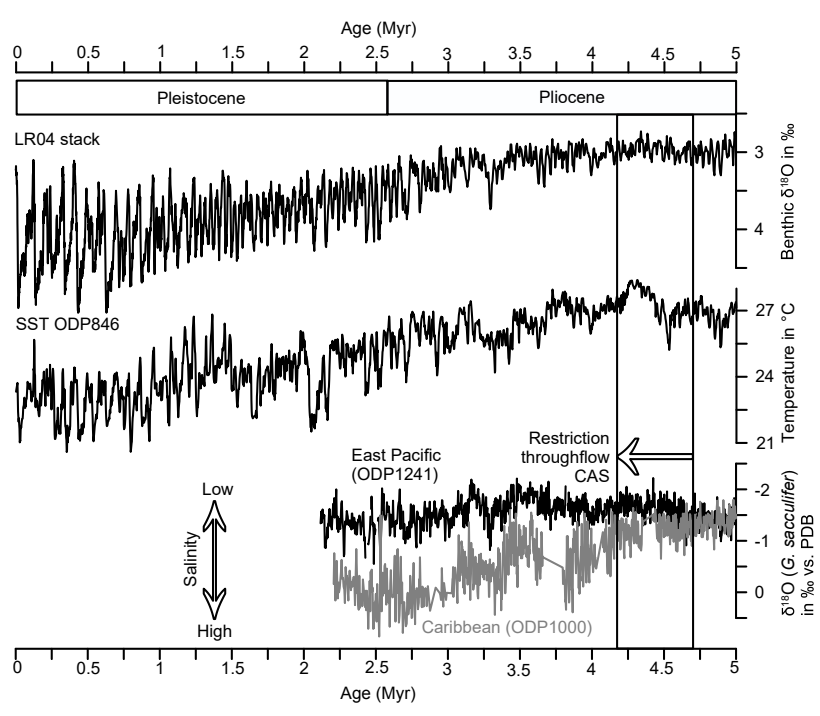

Figure 1. LR04 global stack of benthic $\delta^{18} \mathrm{O}$ reflecting changes in global ice volume and temperature (Lisiecki and Raymo, 2005). $\mathrm{U}_{37}^{\mathrm{K}^{\prime}}$ sea-surface temperature (SST) of ODP Site 846 in the equatorial Pacific cold tongue (Lawrence et al., 2006). $\delta^{18} \mathrm{O}$ of the planktonic foraminifer G. sacculifer from ODP Site 1000 in the Caribbean and ODP Site 1241 in the eastern Pacific (Haug et al., 2001; Steph, 2005; Steph et al., 2006a), reflecting changes in seasurface salinity (see Fig. 2 for location of ODP sites). The box represents the time window analyzed in this study.

(ITCZ; Steph, 2005; Steph et al., 2006a, b, 2010). The direction of a potential shift of the ITCZ is still debated because of a discrepancy between paleoclimate reconstructions based on proxy data and numerical modeling results.

For the late Miocene, a northernmost paleoposition of the ITCZ at about $10-12^{\circ} \mathrm{N}$ has been proposed (Flohn, 1981; Hovan, 1995). Subsequently, a southward shift towards $5^{\circ} \mathrm{N}$ paleolatitude between 5 and $4 \mathrm{Ma}$ is indicated by eolian grain size distributions in the eastern tropical Pacific (Hovan, 1995). Billups et al. (1999) provide additional evidence for a southward shift of the ITCZ between 4.4 and 4.3 Ma. Hence, most proxy data agree about a southward ITCZ shift during the early Pliocene. In contrast, results from numerical modeling suggest a northward shift of the ITCZ in response to CAS closure (Steph et al., 2006b) and Andean uplift (Feng and Poulsen, 2014; Takahashi and Battisti, 2007).

An independent record of the terrestrial hydrology for the early Pliocene from a study site that is sensitive to latitudinal ITCZ shifts could provide new insights to this debate. Schneider et al. (2014) also stress the need for reconstructions of the ITCZ in the early and mid-Pliocene in order to understand how competing effects like an ice-free Northern Hemisphere and a weak EEP CT balanced, and to reduce uncertainties of predictions. Even though changes of oceanatmosphere linkages related to ENSO (El Niño-Southern Oscillation) and ITCZ shifts strongly impact continental precip- itation in western equatorial South America, most studies so far have focused on paleoceanographic features such as seasurface temperature (SST) and ocean stratification.

The second major tectonic process is the uplift of the Northern Andes, which strongly altered atmospheric circulation patterns over South America. Three major deformation phases include fan building in the lower Eocene to early Oligocene, compression of Oligocene deposits in the Miocene and Pliocene, and refolding during Pliocene to Recent times (Corredor, 2003). While the uplift of the Central Andes is well investigated, only few studies deal with the timing of uplift of the Northern Andes. Coltorti and Ollier (2000), based on geomorphologic data, conclude that the uplift of the Ecuadorian Andes started in the early Pliocene and continued until the Pleistocene. More recent apatite fission track data indicate that the Western Andean Cordillera of Ecuador was rapidly exhumed during the late Miocene (13$9 \mathrm{Ma}$ ) (Spikings et al., 2005). Uplift estimates for the Central Andes suggest that the Altiplano had reached less than half of its modern elevation by $10 \mathrm{Ma}$, with uplift rates increasing from $0.1 \mathrm{~mm} \mathrm{yr}^{-1}$ in the early and middle Miocene to $0.2-$ $0.3 \mathrm{~mm} \mathrm{yr}^{-1}$ to present. For the Eastern Cordillera of Colombia, elevations of less than $40 \%$ of the modern values are estimated for the early Pliocene, then increasing rapidly at rates of $0.5-3 \mathrm{~mm} \mathrm{yr}^{-1}$ until modern elevations were reached around $2.7 \mathrm{Ma}$ (Gregory-Wodzicki, 2000). Both the tectonic events and the closure of the Central American Seaway are assumed to have had a large impact on ocean and atmospheric circulation in the eastern Pacific, in the Caribbean, and on adjacent land masses. Therefore, the reconstruction of continental climate, especially hydrology, will contribute to our understanding of climatic changes in this highly complex area.

To better understand the early Pliocene vegetation and hydrology of western equatorial South America, we studied pollen and spores from the early Pliocene section (4.74.2 Ma) of the marine sediment record at Ocean Drilling Program (ODP) Site 1239 and compared this record to Holocene samples from the same site. In addition, we use elemental ratios to estimate variations in fluvial terrestrial input (RínconMartínez et al., 2010). While other palynological studies of the region have been conducted for the mid-Pliocene to Holocene (González et al., 2006; Hooghiemstra, 1984; Seilles et al., 2016), only a few palynological records for the early Pliocene exist (Wijninga and Kuhry, 1990; Wijninga, 1996). The record contributes to elucidating how vegetation and climate in this area responded to changes in atmospheric and oceanic circulation, possibly induced by the closure of the Central American Seaway and the uplift of the Northern Andes. Therefore the main objectives of the study are, firstly, to investigate long-term vegetation and climatic changes, focusing on hydrology, in western equatorial South America and, secondly, to interpret these changes in relation to climate phenomena influencing the hydrology of the region, especially the mean latitudinal position of the ITCZ and vari- 
ability related to ENSO. These objectives are approached through the following research questions: (1) what floral and vegetation changes took place in the coastal plain of western equatorial South America and the Ecuadorian Andes from 4.7 to $4.2 \mathrm{Ma}$ ? (2) What are the climatic implications of the vegetation change, especially in terms of hydrology? (3) What are the implications for Andean uplift, especially regarding the development of the high Andean páramo vegetation?

\subsection{Modern setting}

\subsubsection{Climate and ocean circulation}

The climate of western equatorial South America is complex and heterogeneous, as it is not only controlled by large-scale tropical climate phenomena such as the ITCZ and ENSO but is also strongly influenced by small-scale climate patterns caused by the diverse Andean topography (Marchant et al., 2001; Niemann et al., 2010). The annual cycle of precipitation in northwestern South America is controlled by insolation changes. During boreal summer when insolation is strongest in the Northern Hemisphere, the ITCZ is located at its northernmost position around $9-10^{\circ} \mathrm{N}$ (Vuille et al., 2000). Approaching austral summer, the ITCZ moves southward across the Equator. Within the range of the ITCZ, annual precipitation patterns are generally characterized by two minima and two maxima. The coastal areas of southern Ecuador where the ITCZ has its southernmost excursion show an annual precipitation pattern with one maximum during austral summer and a pronounced dry season during austral winter (Bendix and Lauer, 1992).

This general circulation pattern is modified by ENSO at interannual timescales. During warm El Niño events, the lowlands of Ecuador experience abundant precipitation, whereas the northwestern Ecuadorian Andes experience drought (Vuille et al., 2000). Regional climate patterns are also modified by the topography of the Andes, which pose an effective barrier for the large-scale atmospheric circulation. While precipitation patterns east of the Andes are driven by moisture-laden easterly trade winds originating over the tropical Atlantic and the Amazon Basin, the coastal areas and the western Andean slopes are dominated by air masses originating in the Pacific (Vuille et al., 2000, Fig. 2). The warm annual El Niño current which flows southward along the Colombian Pacific coast warms the air masses along the coast. This moist air brings over $6000 \mathrm{~mm}$ yearly precipitation to the northern coastal plain. In contrast, the coastal areas of southernmost Ecuador and northern Peru are under the influence of the Peru-Chile Current, which is a continuation of the cold Humboldt Current transporting cold and nutrientrich waters and giving rise to a long strip of coastal desert (Balslev, 1988). The westward flow of the cold surface waters of the EEP CT to the western Pacific via the South Equatorial Current (SEC) is driven by the Walker circulation. Warm waters return eastwards via the North Equatorial Countercurrent (NECC; see Fig. 2). An abrupt transition between the cold SEC and the warm NECC is the equatorial front (EF; Pak and Zaneveld, 1974).

\subsubsection{Geography, vegetation, and pollen transport}

Ecuador is geographically divided into three main regions: the coastal plain with several rivers draining into the $\mathrm{Pa}$ cific, the Andes, and the eastern lowlands which constitute the western margin of the Amazon Basin. The mountains form two parallel cordilleras which are separated by an interAndean valley. The diverse vegetation is the result of the combined effects of elevation and precipitation. In the coastal plain there is an abrupt shift from tropical lowland rainforests in the north to a desert dominated by annual xerophytic herbs in the south. This shift reflects the dependence of the vegetation on precipitation, which ranges from 100 to $6000 \mathrm{~mm}$ per year on the coastal plain. The western slopes of the Andes are covered by montane forest, which is partly interrupted by drier valleys in southern Ecuador (Balslev, 1988).

Along the coast, mangrove stands occur in the salt- and brackish-water tidal zone of river estuaries and bays. They are formed by two species of Rhizophora ( $R$. harrisonii and $R$. mangle), and to a lesser extent Avicennia, Laguncularia, and Conocarpus are present (Twilley et al., 2001). The lowland rainforest is characterized by the dominant plant families Fabaceae, Rubiaceae, Arecaceae, Annonaceae, Melastomataceae, Sapotaceae, and Clusiaceae in terms of species richness. In the understory, Rubiaceae, Araceae, and Piperaceae form the predominant elements (Gentry, 1986). In the lower montane forest, Cyathea, Meliaceae (e.g., Ruagea), Fabaceae (e.g., Dussia), Melastomataceae (e.g., Meriania, Phainantha), Rubiaceae (e.g., Cinchona), Proteaceae (e.g., Roupala), Lauraceae (e.g., Nectandra), and Pteridaceae (e.g., Pterozonium) are common elements. Upper montane forests are dominated by Myrsine, Ilex, Weinmannia, Clusia, Schefflera, Myrcianthes, Hedyosmum, and Oreopanax (Jørgensen and León-Yánez, 1999). Above ca. 3200 m, trees become sparse and eventually the vegetation turns into páramo. The páramo is a unique ecosystem of the high altitudes of the Northern Andes of South America and of southern Central America, located between the continuous forest line and the permanent snow line at about 3000-5000 m (Luteyn, 1999). The grass páramo is formed by tussock grasses, mainly Calamagrostis and Festuca. These are complemented by shrubs of Diplostephium, Hypericum, and Pentacalia, and forest patches of Polylepis. The shrub páramo consists of cushion plants like Azorella, Plantago, and Werneria, and shrubs like Loricaria and Chuquiraga. The vegetation of the desert páramo is scarce. Some common taxa are Nototriche, Draba, and Culcitium (Sklenár and Jorgensen, 1999).

Ríncon-Martínez et al. (2010) showed that the terrigenous sediment supply at ODP Site 1239 during Pleistocene interglacials is mainly fluvial and that input of terrestrial material 
(a)

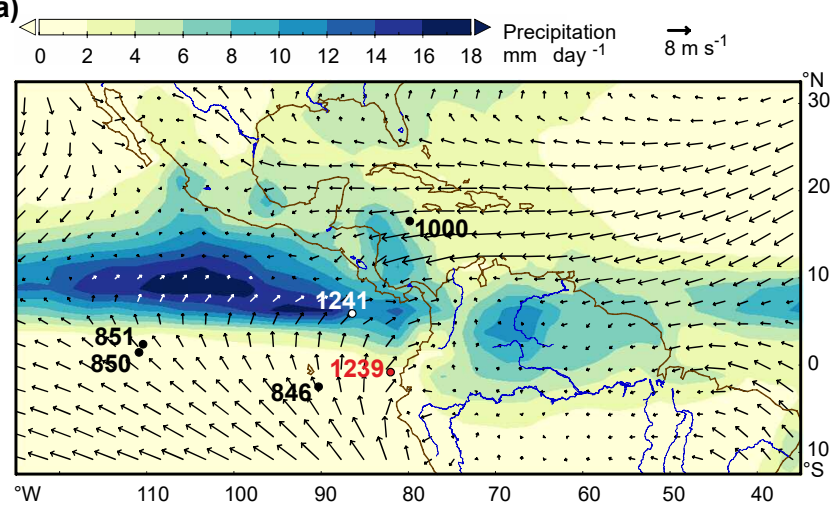

(b)

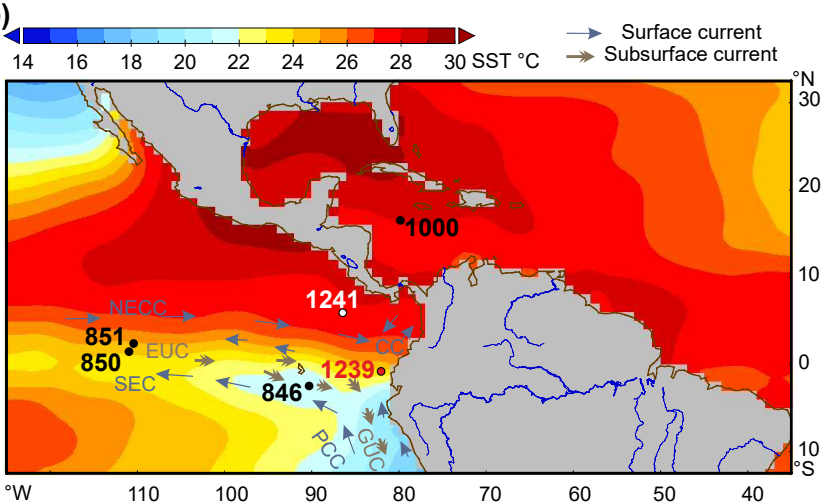

(c)

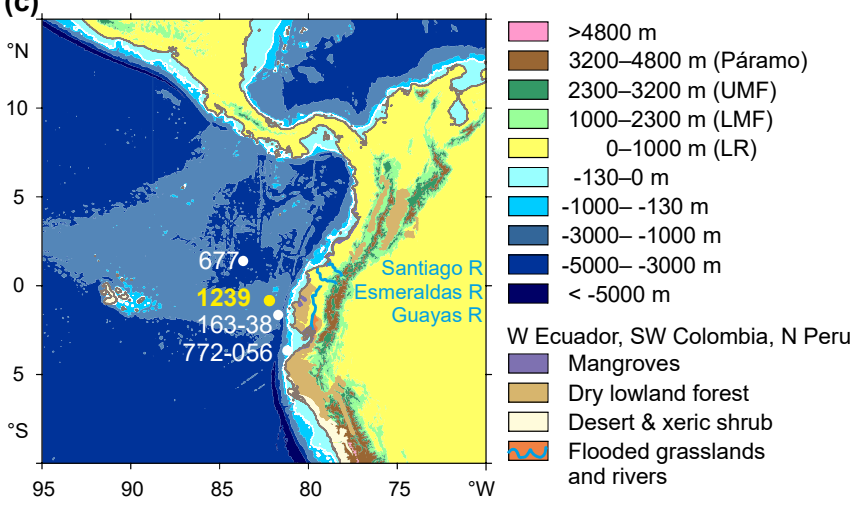

Figure 2. Modern climate (boreal summer) and vegetation and core site positions of ODP sites 677, 846, 850, 851, 1000, 1239, and 1241; Trident core TR163-38; and M772-056 mentioned in the text. (a) 1981-2010 CE long-term monthly July precipitation in millimeters per day (CPC Merged Analysis of Precipitation, https://www.esrl.noaa.gov/psd/data/gridded/data.ncep.reanalysis.derived.html, last access: February 2008 ) and $0.995 \sigma$ level (near-surface) wind field (NCEP). July is the middle of the rainy season in northern South America, when the ITCZ is at its northern boreal summer position. Salinity estimates for the Caribbean indicate a position of the ITCZ further north during the Pliocene. Direction of wind is not favorable for wind transport of pollen and spores to ODP Site 1239. (b) Long-term monthly July sea-surface temperatures (NODC), and surface and subsurface currents of the eastern equatorial Pacific (Mix et al., 2003). NECC, North Equatorial Countercurrent; SEC, South Equatorial Current; PCC, Peru-Chile Current (continuation of the Humboldt Current); CC, Coastal Current; EUC, Equatorial Undercurrent; GUC, Gunther Undercurrent. (c) Contours, bathymetry (ETOPO1), main rivers in Ecuador, and vegetation. Transport of pollen and spores in the ocean over the Peru-Chile Trench, which is very narrow east of the Carnegie Ridge, probably takes place in nepheloid layers. Páramo vegetation is found between 3200 and $4800 \mathrm{~m}$; upper montane Andean forest (UMF) grows between 1000 and $2300 \mathrm{~m}$, sub-Andean lower montane forest (LMF) between 1000 and $2300 \mathrm{~m}$, and lowland forest (LR) below $1000 \mathrm{~m}$. The distribution of desert and xeric shrubs in northern Peru and drier broad-leaved forest, flooded grasslands, and mangroves in Ecuador and Colombia is denoted in different colors (see legend, WWF). Source areas of pollen and spores in sediments of ODP Site 1239 are sought in western Ecuador, northwestern Peru, and southwestern Colombia (see text). Abbreviated Web sources and retrieval dates are listed in the reference list. 
drops to low amounts during the drier glacial stages. Consequently, transport of pollen and spores to the ocean is also mainly fluvial (González et al., 2006). High rates of orographic precipitation characterize the western part of equatorial South America. These heavy rains quickly wash out any pollen that might be in the air and result in large discharge by the Ecuadorian rivers (Fig. 2). The Esmeraldas and Santiago rivers mainly drain the northern coastal plain of Ecuador, and the southern coastal plain is drained by several smaller rivers, which end in the Guayas River (Balslev, 1988). Moreover, the predominantly westerly winds (Fig. 2) are not favorable for eolian pollen dispersal to the ocean. Nevertheless, some transport by SE trade winds is possible and should be taken into account.

After reaching the ocean, pollen and spores might pass the Peru-Chile Trench - which is quite narrow along the Carnegie Ridge - by means of nepheloid layers at subsurface depths. Some northward transport from the Bay of Guayaquil by the Coastal Current (Fig. 2) is likely. However, the PeruChile Current flows too far from the coast to have strong influence on pollen and spore dispersal. We consider western Ecuador, northernmost Peru, and southwestern Colombia the main source areas of pollen and spores in sediments of ODP Site 1239

\subsubsection{Drilling site}

ODP Site 1239 is located at $0^{\circ} 40.32^{\prime} \mathrm{S}, 82^{\circ} 4.86^{\prime} \mathrm{W}$, about $120 \mathrm{~km}$ offshore Ecuador at a water depth of $1414 \mathrm{~m}$, near the eastern crest of Carnegie Ridge and just next to a downward slope into the Peru-Chile Trench (Mix et al., 2003). Its location is close to the equatorial front (Fig. 2), which separates the warm and low-salinity waters of Panama Basin from the cooler and high-salinity surface waters of the EEP CT. The region of Site 1239 reveals a thick sediment cover, with dominant sediments in the region being foraminifer-bearing diatom nannofossil ooze (Mix et al., 2003). A tectonic backtrack path on the Nazca plate (Pisias, 1995) reveals a paleoposition of Site 1239 about 150-200 km further westward (away from the continent) and slightly southward relative to South America at 4-5 Ma compared to the present-day position (Mix et al., 2003). Due to its proximity to the Ecuadorian coast, Site 1239 is suitable for recording changes in fluvial runoff, related to variations of precipitation in northwestern South America. Most of the material is discharged by the Guayas River and Esmeraldas River (Rincón-Martínez et al., 2010).

\section{Methods}

A total of 65 samples of $10 \mathrm{~cm}^{3}$ volume have been analyzed. For the interval between 301 and $334 \mathrm{~m}$ b.s.f. (4.7 and $4.2 \mathrm{Ma}$ ), 46 sediment samples were taken at $67 \mathrm{~cm}$ intervals on average from ODP Hole 1239A (cores 33X5-37X1). Seventeen samples were taken more or less regularly distributed over the rest of the upper $450 \mathrm{~m}$ of Hole A (until 6 Ma). Additionally, two core top samples were taken from ODP Hole 1239B as modern analogues. Standard analytical methods were used to process the samples, including decalcification with $\mathrm{HCl}(\sim 10 \%)$ and removal of silicates with $\mathrm{HF}$ ( $\sim 40 \%)$. Two tablets of exotic Lycopodium spores (batch no. 177745 containing $18584 \pm 829$ spores per tablet) were added to the samples during the decalcification step for calculation of pollen concentrations (grains per cubic centimeter). After neutralization with $\mathrm{KOH} \mathrm{(40 \% )} \mathrm{and} \mathrm{washing,} \mathrm{the}$ samples were sieved with ultrasound over an $8 \mu \mathrm{m}$ screen to remove smaller particles. Samples were mounted in glycerin, and a minimum of 100 pollen/spore grains (178 on average, Fig. S1 in Supplement) were counted in each sample using a Zeiss Axioskop and $400 \times$ and $1000 \times$ (oil immersion) magnification.

For pollen identification, the Neotropical Pollen Database (Bush and Weng, 2007), a reference collection for neotropical species held at the Department of Palynology and Climate Dynamics in Göttingen, and related literature (Colinvaux et al., 1999; Hooghiemstra, 1984; Murillo and Bless, 1974, 1978; Roubik and Moreno, 1991) were used. Pollen types were grouped according to their main ecological affinity (Flantua et al., 2014; Marchant et al., 2002). The zonation of the diagrams was based on constrained incremental sum-of-squares cluster analysis (CONISS) of the pollen percentage curves, using the square root transformation method (Edwards \& Cavalli-Sforza's chord distance) implemented in TILIA (Grimm, 1991; Supplement). Percentages are based on the pollen sum, which includes all pollen and fern spore types, including unidentifiable ones. Confidence intervals were calculated after Maher (1972). An initial age model for Site 1239 was established based on biostratigraphic information (Mix et al., 2003). The age model was refined by matching the benthic stable isotope records from Site 1239 with those from Site 1241 by visual identification of isotope stages (Tiedemann et al., 2007). Site 1241 has an orbitally tuned age model. Thus, this procedure resulted in an indirectly orbitally tuned age model for Site 1239, spanning the interval from 5 to $2.7 \mathrm{Ma}$ (Tiedemann et al., 2007; Fig. S2). A coring gap of ca. $5 \mathrm{~m}$ exists between cores $35 \mathrm{X}(347 \mathrm{~m}$ composite depth) and 36X (352 m composite depth) of Hole 1239A (Tiedemann et al., 2007; Table AT3).

Elemental concentrations (total elemental counts) of $\mathrm{Fe}$ and $\mathrm{K}$ were measured at high resolution (every $2 \mathrm{~cm}$ ) using an Avaatech ${ }^{\mathrm{TM}} \mathrm{X}$-ray fluorescence (XRF) core scanner at the Alfred Wegener Institute, Bremerhaven, with correction for dead time. Both holes A and B of ODP Site 1239 were sampled. A nondestructive measuring technique was applied, allowing rapid semi-quantitative geochemical analysis of sediment cores (Richter et al., 2006). Several studies comparing XRF core scanner data to geochemical measurements on discrete samples showed that major elements can be precisely measured with the scanner in a nondestructive way (e.g., Tjallingii et al., 2007). 


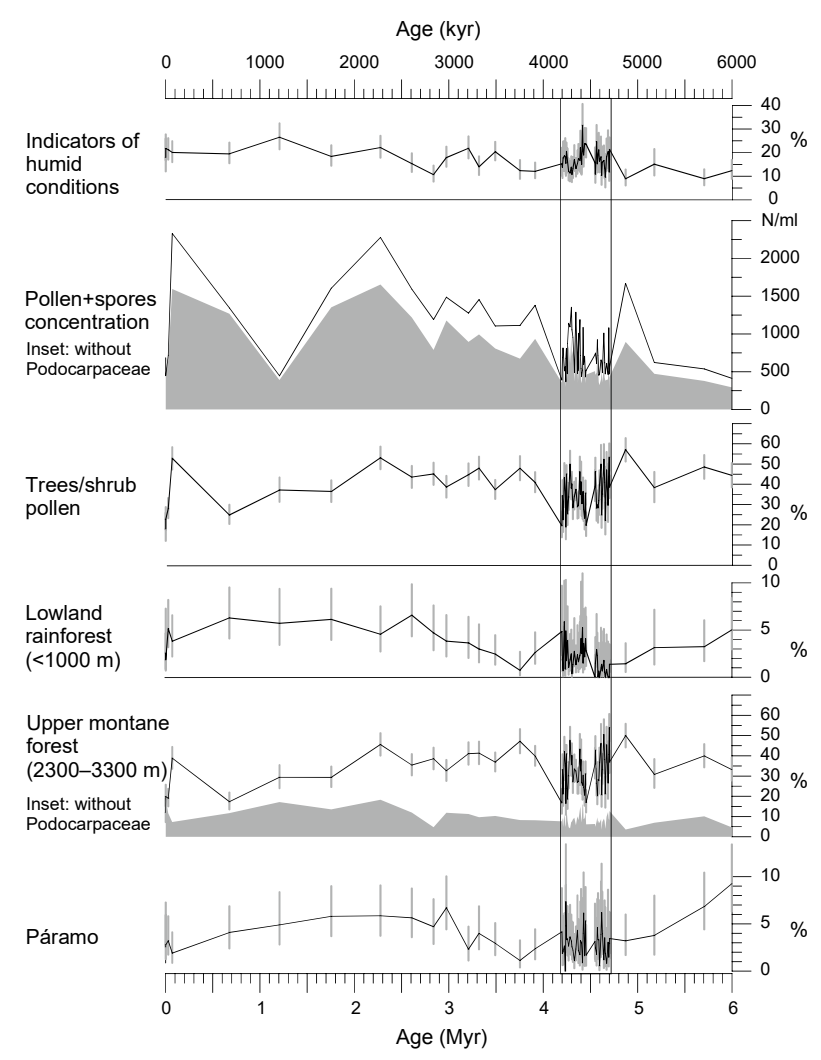

Figure 3. Pliocene and Pleistocene palynomorph percentages (based on the total of pollen and spores) of ODP Hole 1239A for three vegetation belts, humidity indicators, grass pollen, and pollen and spore concentration per milliliter. $95 \%$ confidence intervals as grey bars after Maher (1972). Age model for the last 5 Myr after Tiedemann et al. (2007) and for 6 to 5 Myr after Mix et al. (2003).

\section{Results}

Five groups were established with pollen taxa grouped according to their main ecological affinity (Table 1). The groups páramo, upper montane forest, lower montane forest, and lowland rainforest represent vegetation belts with different altitudinal ranges (Hooghiemstra, 1984; Van der Hammen, 1974). To track changes of humidity, an additional group named "indicators of humid conditions" was established. This group includes those taxa that permanently need humid conditions to grow. Changes of the pollen percentages of the ecological groups for the Pliocene interval and the core top samples are shown in Figs. 3 and 5. Pollen percentages of single taxa are shown in Fig. S1.

To put the results of the detailed early Pliocene section into context of long-term changes, we plot a selection together with the results of a coarse-resolution pilot study in Fig. 3. Percentages of humidity indicators hint to slightly drier conditions at the beginning of the Pliocene. A trend towards higher palynomorph concentrations is found for the period from 6 to 2 Ma. Grass pollen percentages remain low, indicating mainly closed forest at altitudes below the páramo. Representation of lowland rainforest was low around 4.7 Ma, increased by $4.5 \mathrm{Ma}$, declined again to low levels around 3.5 Ma, and rose to remain at higher levels during the Pleistocene. Continuous presence of pollen and spores from the páramo indicates that the Ecuadorian Andes had reached high altitudes before the Pliocene.

\subsection{Description of the early Pliocene pollen record}

In the early Pliocene samples, 141 different palynomorph types were recognized, including 77 pollen and 64 fern spore types. A high percentage of tree and shrub pollen (46\%$88 \%$ ) is present throughout the interval, compared to low percentages of herbs and grass pollen ( $0 \%-25 \%$; Fig. 4). In most of the vegetation belts, one or two pollen or spore taxa are overrepresented. The lowland rainforest is mainly represented by Polypodiaceae, the lower montane forest is controlled by Cyatheaceae, and the upper montane forest is strongly influenced by Podocarpaceae and Hedyosmum. In the páramo, the percentages of the pollen taxa are more evenly balanced. Of the total sum, the Andean forest pollen makes up by far the largest percentage, with the upper montane forest ranging between $17 \%$ and $54 \%$ and the lower montane forest between $5 \%$ and $19 \%$. The páramo is represented with $0 \%$ to $10 \%$, and the lowland rainforest with $0 \%$ to $6 \%$. The remaining fraction has a wide or unknown ecological range.

The pollen record of ODP Hole 1239A was divided into four main pollen zones based on constrained cluster analysis (Fig. 4 and Fig. S1). Pollen zone I (333.4-325.2 m b.s.f.: 4.70-4.58 Ma, 14 samples) has low pollen and spore concentrations. It is characterized by low pollen percentages of lowland rainforest, increases in pollen values of lower montane forest, the percentage of fern spores, and the $\mathrm{Fe} / \mathrm{K}$ ratio. The pollen concentrations of broad range taxa, upper montane forest, páramo, and indicators of humid conditions go through frequent fluctuations. Coastal desert herbs (Amaranthaceae) are well represented (Fig. S1). Percentages of Poaceae pollen are low. In pollen zone II (324.8316.4 mb.s.f.: $4.46-4.42 \mathrm{Ma}, 10$ samples), the pollen and spore concentration is similar to pollen zone I. The lowland rainforest pollen, indicators of humid conditions, and the $\mathrm{Fe} / \mathrm{K}$ ratio reach their maximum. Fern spores also reach their first maximum. Percentages of lower montane forest and páramo are high, whereas the percentage of upper montane forest is low at this time due to a strong decline of Podocarpaceae pollen. The representation of broad range taxa diminishes in the interval above the gap, the decrease being mainly controlled by Selaginella, Cyperaceae, Ambrosia/Xanthium, and Amaranthaceae. Pollen zone II encloses a coring gap of almost $100 \mathrm{ka}$. Pollen zone III (315.5$305.4 \mathrm{~m}$ b.s.f.: $4.41-4.26 \mathrm{Ma}$, 14 samples) shows a stepwise increase of the pollen and spore concentration with its maximum at $4.3 \mathrm{Ma}$. The concentration is strongly controlled 
Table 1. List of identified pollen and spore taxa in marine ODP holes 1239A (Pliocene samples) and 1239B (core top samples; taxa in bold occurred only in core top samples) and grouping according to their main ecological affinity (Flantua et al., 2014; Marchant et al., 2002).

\begin{tabular}{|c|c|c|c|c|c|}
\hline Páramo & Upper montane forest & Lower montane forest & $\begin{array}{l}\text { Lowland } \\
\text { rainforest }\end{array}$ & $\begin{array}{l}\text { Broad range } \\
\text { taxa }\end{array}$ & $\begin{array}{l}\text { Humid } \\
\text { indicators }\end{array}$ \\
\hline Polylepis/Acaena & Podocarpaceae & Urticaceae/ Moraceae & Wettinia & Poaceae & Cyperaceae \\
\hline Jamesonia/ Eriosorus & Hedyosmum & Erythrina & Socratea & Cyperaceae & Ranunculus \\
\hline Huperzia & Clethra & Alchornea & Polypodiaceae & $\begin{array}{l}\text { Tubuliflorae } \\
\text { (Asteraceae) }\end{array}$ & Hedyosmum \\
\hline Ranunculus & Morella & Styloceras $\mathrm{T}$ & $\begin{array}{l}\text { Pityrogrammal } \\
\text { Pteris altissima } \mathrm{T}\end{array}$ & Amaranthaceae & Ilex \\
\hline Draba & Acanthaceae & Malpighiaceae & & Rosaceae & Pachira \\
\hline Sisyrinchium & Melastomataceae & Cyatheaceae & & Ambrosial Xanthium & Morella \\
\hline \multirow{14}{*}{$\begin{array}{l}\text { Cystopteris } \\
\text { diaphana } \mathrm{T}\end{array}$} & Daphnopsis & Vernonia $\mathrm{T}$ & & Ericaceae & Malpighiaceae \\
\hline & Bocconia & Pteris grandifolia $\mathrm{T}$ & & Artemisia & Cyatheaceae \\
\hline & Myrsine & Pteris podophylla $\mathrm{T}$ & & Ilex & Selaginella \\
\hline & Lophosoria & Saccoloma elegans $\mathrm{T}$ & & Thevetia & $\begin{array}{l}\text { Pityrogramma/Pteris } \\
\text { altissima } \mathrm{T}\end{array}$ \\
\hline & Elaphoglossum & Thelypteris & & Salacia & Hymenophyllum $\mathrm{T}$ \\
\hline & Hypolepis hostilis $\mathrm{T}$ & Ctenitis subincisa $\mathrm{T}$ & & Bromeliaceae & Thelypteris \\
\hline & Grammitis & & & Malvaceae & Ctenitis subincisa $\mathrm{T}$ \\
\hline & $\begin{array}{l}\text { Dodonaea } \\
\text { viscosa }\end{array}$ & & & Euphorbiaceae & Alnus \\
\hline & Alnus & & & Liliaceae & $\begin{array}{l}\text { Cystopteris } \\
\text { diaphana T }\end{array}$ \\
\hline & & & & Lycopodiaceae excl. & \\
\hline & & & & Huperzia & \\
\hline & & & & Selaginella & \\
\hline & & & & Hymenophyllum $\mathrm{T}$ & \\
\hline & & & & Calandrinia & \\
\hline
\end{tabular}

by Podocarpaceae pollen, which accounts for up to $44 \%$ in this zone. The pollen of lowland rainforest, lower montane forest, páramo, indicators of humid conditions, and $\mathrm{Fe} / \mathrm{K}$ show lower values than in zone II. Broad range taxa show some larger fluctuations. The upper montane forest pollen has its maximum extent of this zone ( $48 \%$ ) at 4.28 Ma due to the high percentage of Podocarpaceae. If the Podocarpaceae pollen is excluded from the upper montane forest, the representation of this vegetation belt shows the same pattern of decline as that of the lower montane forest and lowland rainforest. In pollen zone IV (304.7-301.3 m b.s.f.: 4.25-4.12 Ma, 8 samples), the pollen and spore concentration decreases sharply after $4.24 \mathrm{Ma}$. The pollen percentage of lower montane forest increases. The percentage of fern spores is at its maximum in this zone. Percentages of páramo, upper montane forest, broad range taxa, indicators of humid conditions, and the $\mathrm{Fe} / \mathrm{K}$ ratio remain similar to those in zone III. The percentage of lowland rainforest pollen goes through frequent and large fluctuations.

\subsection{Modern vs. Pliocene pollen assemblages}

Two samples from the top of ODP Hole 1239B have been analyzed to facilitate a comparison of the recent palynological signal with modern vegetation (Fig. 5 and Fig. S1). Although there is no detailed age control on these surface/subsurface samples, a Holocene age can be assigned based on the ben- thic oxygen isotope record (Rincón-Martínez et al., 2010). Fifty-one different palynomorph types were recognized, including 29 pollen and 22 fern spore types. The samples are characterized by low pollen and spore concentrations of 685 and 465 grains $\mathrm{cm}^{-3}$, respectively. Indicators of humid conditions show intermediate values. Herbs and grass pollen are very abundant with $20 \%-26 \%$, but tree and shrub pollen decreased to $35 \%-46 \%$ compared to the early Pliocene interval. Broad range taxa reach their maximum abundance with $26 \%-27 \%$. Lowland rainforest and páramo pollen have similar representations to those in the Pliocene, whereas the lower and upper montane forest pollen reach their lowest percentages. When compared to the Pliocene pollen composition, some floristic differences are seen. During the Holocene Podocarpus is replaced by Alnus as the most abundant upper montane forest tree, although Podocarpus was still abundant during the glacial period (González et al., 2010). Another notable difference is the presence of Rhizophora pollen in one of the core top samples, whereas it is completely absent in the early Pliocene interval.

\subsection{Description of the páramo}

The pollen spectrum from the páramo at ODP Site 1239 includes three different taxa which are mainly confined to the páramo: the pollen type Polylepis/Acaena and the fern spores Huperzia and Jamesonia/Eriosorus (Fig. 6). Other 


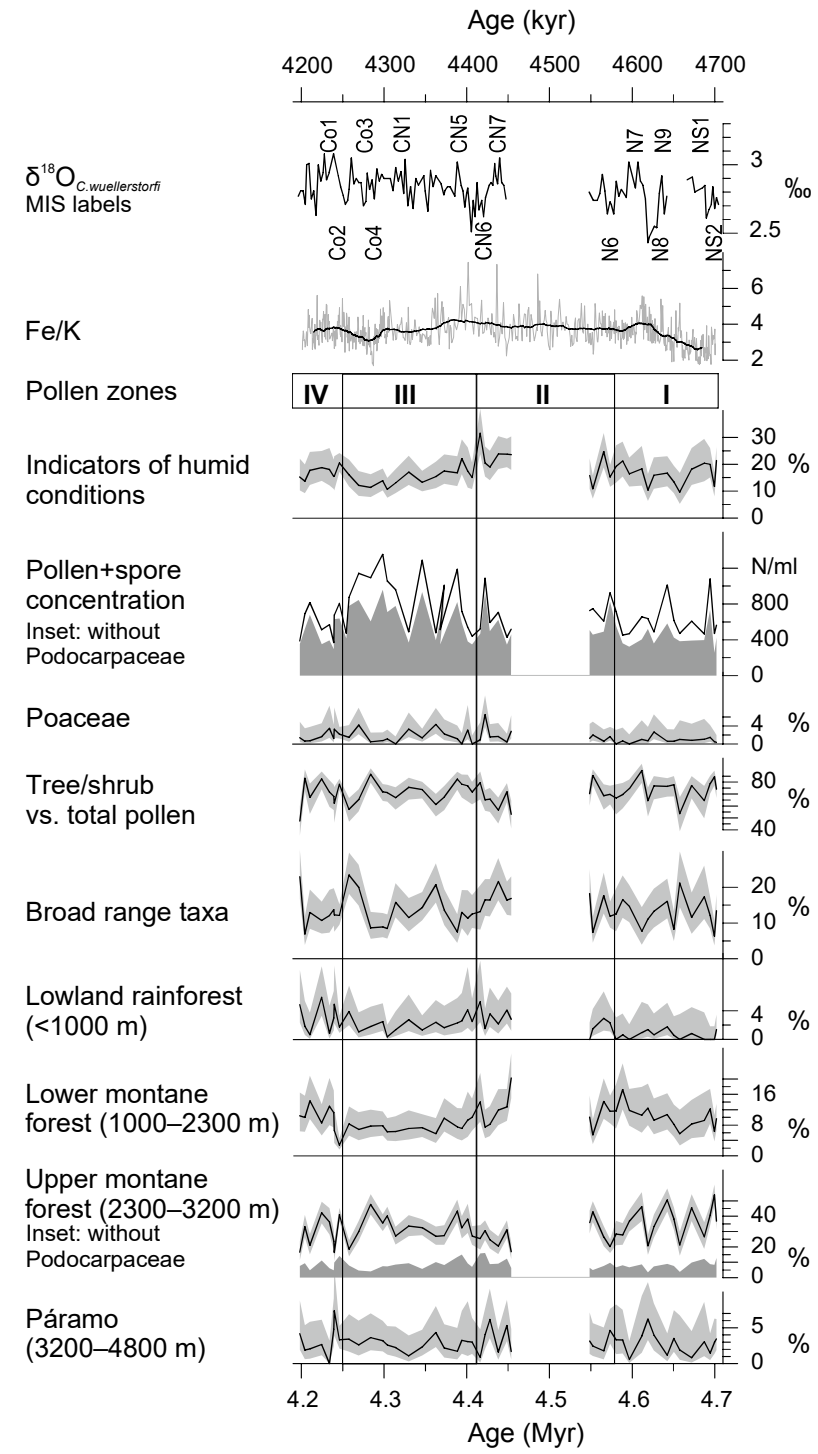

Figure 4. Palynomorph percentages of ODP Hole 1239A for the four vegetation belts and other groups from 4.7 to $4.2 \mathrm{Ma}$. Grey shading represents the $95 \%$ confidence intervals (after Maher, 1972). Vertical black lines delimit the pollen zones. At the top stable oxygen isotopes of the benthic foraminifer $C$. wuellerstorfi (Tiedemann et al., 2007) of ODP Hole 1239A, marine isotope stages (MIS), and elemental ratios of $\mathrm{Fe} / \mathrm{K}$ from holes 1239A and 1239B. Ages are from Tiedemann et al. (2007). A coring gap is present in Hole 1239A between 4.45 and 4.55 Ma.

taxa, which are characteristic of páramos but cannot be exclusively attributed to this ecosystem, were not included in the páramo sum (e.g., Asteraceae, Poaceae, Ericaceae). The record shows the continuous presence of páramo vegetation since at least $6 \mathrm{Ma}$. The summed páramo pollen constitutes up to $9 \%$ of the total pollen and spore sum, with the highest fraction found at the beginning of the record (6 Ma) and

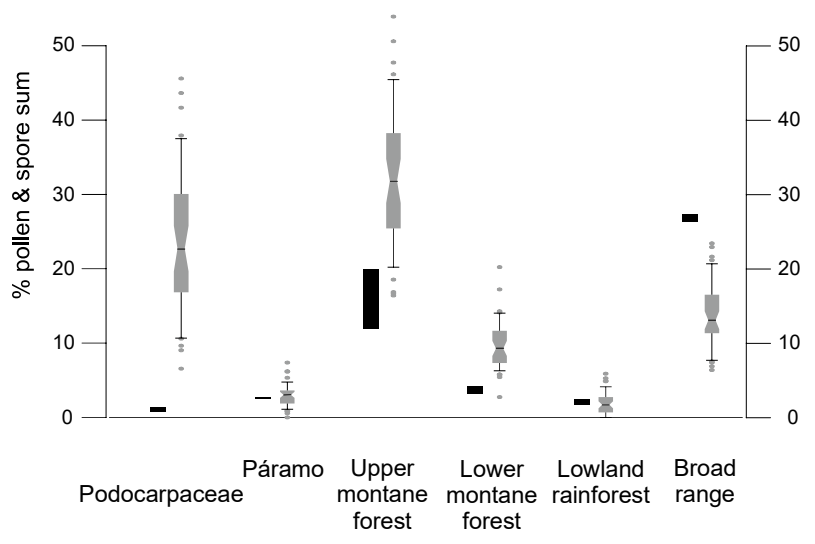

Figure 5. Comparison of the palynomorph percentages (based on total pollen and spores) of Podocarpaceae and the different vegetation belts between two Holocene samples (black) and Pliocene samples between 4.7 and 4.2 Ma (box-whisker plots).

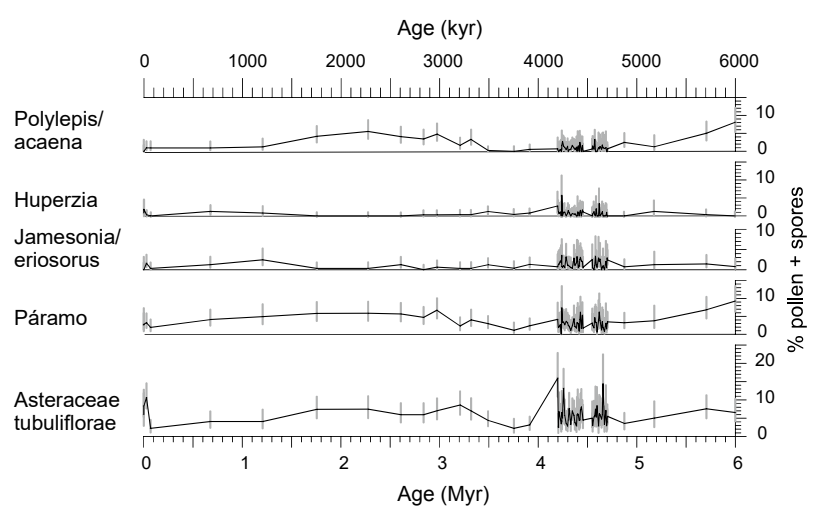

Figure 6. Palynomorph percentages of páramo indicators and Asteraceae Tubuliflorae (excluding Ambrosia/Xanthium T) of the past $6 \mathrm{Myr}$ indicating the presence of páramo vegetation at least since the late Miocene. $95 \%$ confidence intervals (grey bars) after Maher (1972). Ages after Tiedemann et al. (2007) and Mix et al. (2003).

the lowest fractions around 4.23 and $4.59 \mathrm{Ma}$, at ca. $3.75 \mathrm{Ma}$, and during the late Pleistocene (Figs. 4 and 6).

\section{Discussion}

\section{1 $\mathrm{Fe} / \mathrm{K}$ as a tracer for changes in fluvial runoff}

The $\mathrm{Fe} / \mathrm{K}$ ratio has been shown to be a suitable tracer to distinguish between terrigenous input of slightly weathered material from drier regions and highly weathered material from humid tropical latitudes. Sediments from deeply chemically weathered terrains have higher iron concentrations compared to the more mobile potassium (Mulitza et al., 2008). Before paleoclimatic interpretations can be made based on elemental ratios, other processes which possibly influence the dis- 
tribution of $\mathrm{Fe} / \mathrm{K}$ in marine sediments should be examined, like changes of the topography of Andean river drainage basins, the input of mafic rock material, or diagenetic $\mathrm{Fe}$ remobilization (Govin et al., 2012). For northeastern South America it was shown that, during the middle Miocene, uplift of the Eastern Andean Cordillera led to changes in the drainage direction of the Orinoco and Magdalena rivers and to the formation of the Amazon River (Hoorn, 1995; Hoorn et al., 2010). If a similar temporal history of uplift and changing drainage patterns is assumed for the Western Andean Cordillera, the large-scale patterns of the present topography and river drainage basins should have been in place by the early Pliocene. Therefore, the main direction of fluvial transport of Fe should have been similar to today. Diagenetic alteration was shown not to affect Fe concentrations at Site 1239 (Rincón-Martínez, 2013). The Fe/K ratio therefore seems to be an adequate tracer of fluvial input at this study site. The trend of $\mathrm{Fe} / \mathrm{K}$ is similar to the pattern of humidity inferred from the pollen spectrum, showing the highest values around 4.46 Ma, thus supporting the hydrological interpretation of the pollen record.

\subsection{The Holocene as a modern reference}

In order to better understand the source areas and transport ways of pollen grains to the sediments, we make a comparison of the results of our two Holocene samples (Fig. S1) with that of another pollen record retrieved from the Carnegie Ridge southeast of ODP Site 1239 (TR 163-38, Fig. 2) reflecting rainfall and humidity variation of the late Pleistocene (González et al., 2006). Holocene samples of Site 1239 gave similar results showing extensive open vegetation (indicated by pollen of Poaceae, Cyperaceae, Asteraceae) and maximum relative abundance of fern spores although concentration is low (González et al., 2006). As also indicated by the elemental ratios, fluvial transport of pollen predominates in this area (González et al., 2006; Ríncon-Martínez, 2013). This is understandable, as neither ocean currents nor the wind field favor transport from Ecuador to Site 1239 (Fig. 2).

Despite the expansion of open vegetation, González et al. (2006) interpreted this record as reflecting permanently humid conditions, with disturbance processes caused by human occupation and more intense fluvial dynamics. The relatively high percentage of indicators of humid conditions in our core top samples compared to pollen zones III and IV in the early Pliocene would be in agreement with this interpretation. The core top samples from ODP Hole 1239B and the most recent part of core TR 163-38 are taken as a basis for the hydrological interpretation of the Pliocene pollen record.

\subsection{Climatic implications of vegetation change}

The presented marine palynological record provides new information on floristic and vegetation changes occurring along diverse ecological and climatic gradients through the early
Pliocene. The consistently high percentage of tree and shrub pollen, compared to a low percentage of herbs and grass pollen $(<25 \%)$, suggests the predominance of forests and the near absence of open grasslands (apart from páramo) during the early Pliocene. Moreover, the very low percentage of dry indicators (Amaranthaceae) suggests the absence of persisting drought conditions and supports the idea of a rather stable and humid climate that favored a closed forest cover. This is in good accordance with Pliocene climate models suggesting warmer and wetter conditions on most continents, which led to expansions of tropical forests and savannas at the expense of deserts, for instance in Africa (Salzmann et al., 2011). During the early Pliocene, no profound changes in the vegetation occur. All altitudinal vegetation belts are already present, with varying ratios, and only pollen percentages of lowland rainforest rise from almost absent to $6 \%$.

Shifts in the vegetation are driven by various parameters such as temperature, precipitation, $\mathrm{CO}_{2}$, radiation, and any combination thereof. However, a hint to which parameter has the strongest influence on the vegetation might be given by the pattern of expansion and retreat of different vegetation belts. Hooghiemstra and Ran (1994) indicate that, if temperature were the dominant driver of vegetation change, altitudinal shifting of vegetation belts would lead to increase in the representation of one at the cost of another. We hardly see such a pattern in our record with the possible exception of zone III where the trends between pollen percentages of páramo and those of upper montane forest (without Podocarpaceae) are reversed (Sect. 4.3.2; Fig. 8). However, the more general pattern indicates parallel changes in the representation of the forest belts, suggesting that not temperature but humidity had the stronger effect on the Pliocene vegetation of Ecuador.

\subsubsection{Development of the coastal vegetation}

Early Pliocene pollen zones I and IV show an expansion of coastal desert herbs (Amaranthaceae, Fig. S1), which coincides with low sea-surface temperatures at ODP Site 846 in the EEP, suggesting an influence of the Peru-Chile Current (continuation of the Humboldt Current) on the coastal vegetation of southern Ecuador. Remarkably, the lowland rainforest and the coastal desert herbs follow a similar trend. This seems odd at the first glance, but a possible mechanism to explain this pattern would invoke effects of El Niño, the warm phase of ENSO. The main transport agent for pollen in this region are rivers, but in the coastal desert area of southern Ecuador and northern Peru fluvial discharge rates are low (Milliman and Farnsworth, 2011). Therefore, pollen might be retained on land until an El Niño event causes severe flooding in the coastal areas (Rodbell et al., 1999) and episodically fills the rivers which transport the pollen to the ocean. Such possible effects of El Niño seem to be strongest in pollen zones I and IV where pollen percentages of not only the lowland rainforest and coastal desert herbs but also the upper 
montane forest fluctuate most strongly. The lowland rainforest of the coastal plain of Ecuador and western Colombia is within the present-day range of the ITCZ and expanded from 4.7 Ma onwards possibly due to a southwards displacement of the mean latitude of the ITCZ (Figs. 3 and 4).

\subsubsection{Development of the montane vegetation}

Podocarpaceae strongly dominate the pollen spectrum in general. However, the trend in pollen percentages of Podocarpaceae diverges from that of the other pollen taxa, which may be explained by additional transport of Podocarpaceae pollen by wind. The high pollen production of Podocarpaceae and their specialized morphology (Regal, 1982) facilitate their eolian transport. In contrast, pollen from most other taxa is predominantly fluvially transported (González et al., 2006), therefore exhibiting a different pattern where high pollen concentrations correspond to high fluvial discharge in the source area. Eolian transport of Podocarpaceae explains the high pollen concentrations in pollen zone III, which occur despite less humid conditions compared to pollen zones II and IV. The increased eolian transport at $4.63 \mathrm{Ma}$ and between 4.4 and $4.25 \mathrm{Ma}$ is proposed here to be the result of an intensification of the easterly trade winds. Increase in trade wind strength at $4.4 \mathrm{Ma}$ would be in line with a shift in the locus of maximum opal accumulation rates in the ocean associated with a shift in nutrient availability from ODP Site 850 to ODP Site 846 nearer to the continent (positions shown in Fig. 2) (Farrell et al., 1995). Dynamic modeling indicates that stronger easterlies would cause shoaling of the EEP thermocline (Zhang et al., 2012), which took place between 4.8 and 4.0 Ma (Fig. 7; Steph et al., 2006a). Related to this process, a critical step of easterly trade wind intensification, indicated by increased eolian transport of Podocarpaceae pollen, occurred between 4.4 and 4.25 Ma.

Comparing the pollen percentages of páramo and upper montane forest, Fig. 8 indicates that UMF maxima coincide with páramo minima and SST maxima at ODP Site 846 (Lawrence et al., 2006). This might be explained by a shift of the upper montane forest to higher altitudes at the cost of the area occupied by páramo vegetation as a result of higher atmospheric temperatures and/or increased orographic precipitation in the Western Andean Cordillera caused by higher sea-surface temperatures and increased evaporation.

\subsection{Development of the páramo and implications for Andean uplift}

In order to use the existence of páramo vegetation as an indicator for Andean elevation, the altitudinal restriction of the páramo taxa to environments above the forest line is a prerequisite. Although no taxa restricted to páramo were identified in the marine samples, or rather they could not be identified due to the lack of genus-level morphological distinction (es-

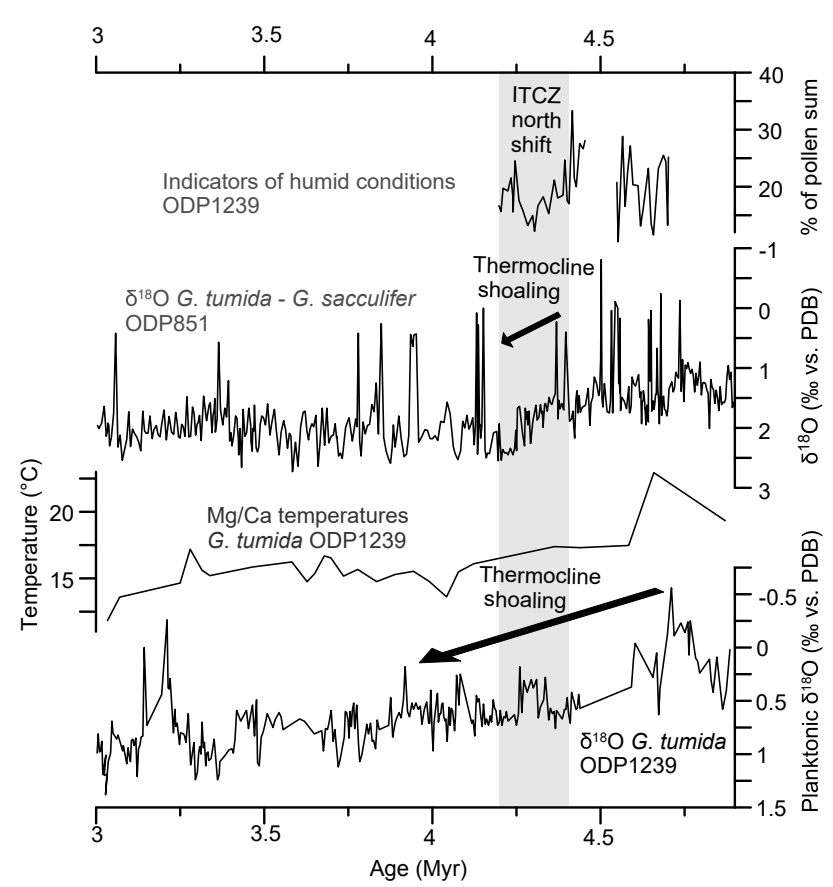

Figure 7. Percentages of indicators of humid conditions (ODP Site 1239, this study), G. tumida-G. sacculifer difference in $\delta^{18} \mathrm{O}$ from ODP Site 851 in the eastern equatorial Pacific (Cannariato and Ravelo, 1997), and G. tumida $\mathrm{Mg} / \mathrm{Ca}$ temperatures and $\delta^{18} \mathrm{O}$ from ODP Site 1239 (Steph, 2005; Steph et al., 2010). Grey shading marks the period of thermocline shoaling at ODP Site 851 and ITCZ north shift.

pecially Espeletia from the Asteraceae and some Poaceae, e.g., Festuca), several taxa are mainly confined to high Andean environments. Dwarf trees of Polylepis typically form patches above the forest line, and its natural altitudinal range is thought to occur between a lower limit which forms the transition to other forest types and up to $5000 \mathrm{~m}$ in Bolivia (Kessler, 2002). Species of Huperzia are found in montane forests as epiphytes and in the páramo with terrestrial habit (Sklenár et al., 2011). Jamesonia and Eriosorus are both found in cool and wet highlands, with most species being found between 2200 and $5000 \mathrm{~m}$ (Sánchez-Baracaldo, 2004). Asteraceae are not restricted to the páramo, but their occurrence in the montane forest and in the lowland rainforest of the Pacific coast is scarce (Behling et al., 1998). With a contribution of up to $16 \%$ of the pollen sum, their source area can be attributed mainly to the páramo. Additionally, the fluctuations are similar to the other páramo taxa (Fig. 6), which is another indication for their common source area.

The pollen record shows a continuous existence of páramo vegetation. During the warm Pliocene, the upper montane forest is assumed to have extended to altitudes similar to or even higher than those of today. Despite this upward expansion of the upper montane forest, the páramo was still present, which implies that the Western Cordillera of the 


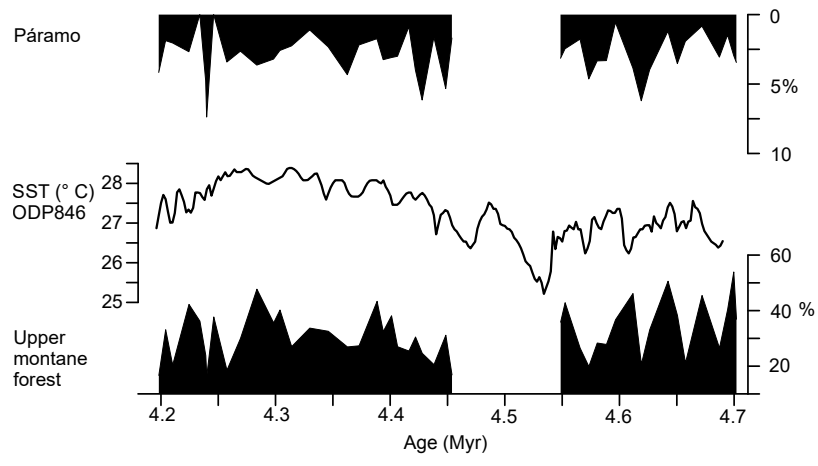

Figure 8. Pollen percentages of upper montane forest and páramo, and $\mathrm{U}_{37}^{\mathrm{K}^{\prime}}$ sea-surface temperature (SST) of ODP Site 846 in the eastern equatorial Pacific (Lawrence et al., 2006).

Ecuadorian Andes had already gone through substantial uplift by that time. Furthermore, the pollen record has a large montane signature, which would not be the case if the Andes had reached less than half of their modern height by the early Pliocene (Coltorti and Ollier, 2000). The upper montane forest, which constitutes up to $60 \%$ of the pollen sum, shows that montane habitats with the corresponding altitudinal belts were already existent. These findings suggest an earlier development of the high Andean páramo ecosystem than previously inferred from palynological studies of the eastern Cordillera in Colombia (Hooghiemstra et al., 2006; Van der Hammen et al., 1973). This might also be an indication that the uplift history of the Western Cordillera of Ecuador is temporally more closely related to the uplift of the Central Andes where a major phase of uplift occurred between 10 and $6 \mathrm{Ma}$ (Garzione et al., 2008). In another recent palynological study, the arrival of palynomorphs from the páramo in sediments of the Amazon Fan has been documented since 5.4 Ma (Hoorn et al., 2017). Since the Amazon has its westernmost source in Peru, this signal might be related to the uplift of the Central Andes. These new records agree with paleoclimatic studies showing that modern type precipitation patterns have likely been in place since the middle Miocene (Barnes et al., 2012; Hoorn et al., 2010; Kaandorp et al., 2006), which would have required a significant orographic barrier. High Andean mountains acting as a climate divide might thus go as far back as the mid-Miocene. However, earliest evidence for páramo vegetation now points to the late Miocene.

\subsection{Comparing models and proxy data}

Several studies have suggested the existence of a "permanent El Niño" during the Pliocene (e.g., Fedorov et al., 2006; Wara et al., 2005). El Niño events are characterized by a shift in the Walker circulation, resulting in exceptionally heavy precipitation particularly over the lowlands of central and southern Ecuador (Bendix and Bendix, 2006) and simultaneous below-average rainfall over the northwestern slopes of the Andes (Vuille et al., 2000). A permanent El Niño-like climate state during the early Pliocene would thus have involved permanently humid conditions with high rates of precipitation and fluvial discharge in the lowlands. Such a climate would have favored the persistence of a broad rain forest coverage and precluded the development of the desert that exists in coastal southern Ecuador today. The presented pollen record indeed indicates very humid conditions, and the only indicator of dry vegetation is a small percentage of Amaranthaceae pollen. The predicted pattern of expansion of lowland rainforest at the cost of Andean forest during permanent El Niño is not reflected in the pollen record.

The hypothesis of a permanent El Niño climate state involving a reduced zonal Pacific sea-surface temperature gradient has recently been questioned as sea-surface temperature reconstructions differ substantially depending on the method. Zhang et al. (2014) claim that a zonal temperature gradient of ca. $3^{\circ} \mathrm{C}$ existed since the late Miocene and even intensified during the Pliocene. Our pollen record instead indicates an influence of periodic El Niño-related variations on the coastal and montane vegetation, especially between 4.7 and $4.55 \mathrm{Ma}$ and between 4.26 and $4.2 \mathrm{Ma}$, recorded by strong fluctuations in the pollen percentages of coastal and montane vegetation. Our record does not show increased representation of one vegetation belt at the cost of another, indicating that altitudinal shifts were not extensive and moisture availability might have been an important driver of Pliocene vegetation change. Changes in humidity could be caused by a latitudinal displacement of the ITCZ. A southward displacement of the ITCZ over both the Atlantic and Pacific has been proposed as a response to stronger zonal temperature and pressure gradients which developed after the restriction of the Central American Seaway and/or a weakening of Southern Hemisphere temperature gradients (Billups et al., 1999). The timing of the southward shift was narrowed down to 4.4 to $4.3 \mathrm{Ma}$ in this study, based on $\delta^{18} \mathrm{O}$ records of planktonic foraminifera. The pollen record suggests a slightly different timing, with a gradual southward displacement of the ITCZ between 4.7 and $4.42 \mathrm{Ma}$, when the southernmost position was reached. A less humid phase - indicated by a decrease of humid indicators, lowland rainforest pollen, lower montane forest pollen, and the $\mathrm{Fe} / \mathrm{K}$ ratio - followed between 4.42 and 4.26 Ma where the ITCZ presumably had a slightly more northern position. This phase coincides with the shoaling of the thermocline at ODP Site 851 in the eastern equatorial Pacific (Cannariato and Ravelo, 1997; Fig. 6). A southward displacement of the ITCZ during the early Pliocene would also be in accordance with eolian deposition patterns in the EEP which show a latitudinal shift in eolian grain size and eolian flux between 6 and $4 \mathrm{Ma}$ (Hovan, 1995). The rather small and slow changes in humidity imply that the ITCZ shift was a gradual process, rather than the response to a single threshold. Just like the Central American Seaway was restricted and reopened several times before its definitive closure at 
around 2.8 Ma (O'Dea et al., 2016), the atmospheric circulation might have adapted gradually in several small steps to these tectonic changes.

Numerical models suggesting a northward shift of the ITCZ in response to the closure of the Central American Seaway or the uplift of the Northern Andes do not necessarily disagree with an early Pliocene southward shift inferred from proxy data. Both events occurred gradually over several millions of years, and, despite recent advances in constraining these events, the timing of major phases in the uplift histories is still debated. In the case of the Central American Seaway, the timing of surface water restriction based on diverging salinities in the Caribbean and Pacific Ocean is well constrained, and numerous global oceanographic changes have been associated with it. Possibly these oceanic reorganizations did not directly trigger modifications of the atmospheric circulation (Kaandorp et al., 2006; Hoorn et al., 2010), but critical periods of uplift influencing atmospheric circulation might have occurred earlier. On the other hand, the respective model sensitivity experiments generally only consider isolated changes in single boundary conditions (e.g., closed or open Central American Seaway). Therefore, the effect of those (i.e., a northward shift of the ITCZ) might counteract the general trend of a southward shift since the late Miocene due to a decrease in the hemispheric temperature gradient (e.g., Pettke et al., 2002). Additionally, global coupled models exhibit uncertainties in the representation of ocean-atmosphere feedback and cloud-radiation feedbacks, which are especially strong in the study region (i.e., showing a double ITCZ and an extensive EEP cold tongue; $\mathrm{Li}$ and $\mathrm{Xie}, 2014)$. This is problematic also in light of the high sensitivity of the ITCZ position to slight shifts in the atmospheric energy balance (Schneider et al., 2014). Another aspect to consider is that, whereas proxy records record the transient response of the climate system over a limited period of time, the mentioned model simulations rather follow the overall equilibrium response than reproducing a stepwise process of environmental changes.

Concerning the uplift of the Northern Andes, there is still a large uncertainty about the time when the Cordilleras reached their current elevation. Moreover, phases of major uplift might have strongly differed regionally. Paleobotanists (e.g., Hooghiemstra et al., 2006; Hoorn et al., 2010; Van der Hammen et al., 1973) and some tectonic geologists (e.g., Mora et al., 2008) argue for a rapid rise of the Eastern Cordillera since 4-6 Ma, while others conclude that this is rather unlikely, implying an earlier uplift based on biomarker-based paleotemperatures (e.g., Anderson et al., 2015; Mora-Páez et al., 2016). Possibly the Pliocene oceanic reorganizations did not directly trigger modifications of the atmospheric circulation, which probably was more or less in place (Kaandorp et al., 2006; Hoorn et al., 2010). Critical periods of uplift influencing atmospheric circulation might have occurred earlier (see also above). The estimates for uplift of the Western Cordillera in Ecuador differ even more strongly and range from rapid exhumation around 13 and $9 \mathrm{Ma}$ based on thermochronology (Spikings et al., 2005) to a recent uplift during the Pliocene and Pleistocene (Coltorti and Ollier, 2000). Our pollen record from the páramo shows that the Ecuadorian Andes must have already reached close to modern elevations by the early Pliocene in line with inferences of Hoorn et al. (2017) and Bermúdez et al. (2015). If an early Andean uplift is assumed, the atmospheric response predicted by the model would have occurred earlier, which would also be in agreement with proxy data indicating a northern position of the ITCZ during the late Miocene (Hovan, 1995).

Overall, even if the timing and identification of major steps in the shoaling and restriction of the Central American Seaway or in the uplift of the Northern Andes are resolved, the critical threshold for profound changes in atmospheric circulation and climate may have occurred at any time during the tectonic processes. Within the analyzed time window, large changes in atmospheric circulation which have been proposed as a response to the closure of the Central American Seaway (Ravelo et al., 2004) are absent.

\section{Conclusions}

Between 4.7 and 4.2 Ma, a permanently humid climate with broad rainforest coverage existed in western equatorial South America. No evidence was found for a permanent El Niñolike climate state, but strong fluctuations in the vegetation between 4.7 and $4.55 \mathrm{Ma}$ and between 4.26 and 4.2 Ma indicate strong periodic El Niño variability at this time. Hydrological changes between 4.55 and $4.26 \mathrm{Ma}$ are attributed to gradual shifts of the Intertropical Convergence Zone, which reached its southernmost position around 4.42 Ma and shifted slightly north afterwards.

The most prominent shift recorded during the early Pliocene is an increase in the representation of the lowland rainforest around 4.5 Ma.

Between 4.41 and $4.26 \mathrm{Ma}$, an increased eolian influx of Podocarpaceae pollen indicates an increased strength of the easterly trade winds, which is presumably related to the shoaling of the EEP thermocline.

Results from proxy data and numerical modeling studies regarding the position of the ITCZ during the early Pliocene are not necessarily contradictory. Considering the temporal uncertainties regarding major steps of CAS closure and uplift of the Northern Andes, the proposed northward shift of the ITCZ in response to these events might have occurred much earlier (e.g., during the middle to late Miocene).

The continuous presence of páramo vegetation since $6 \mathrm{Ma}$ implies that the Ecuadorian Andes had already reached an elevation suitable for the development of vegetation above the upper forest line by the latest Miocene. We present new paleobotanical evidence indicating an earlier development of páramo vegetation than previously suggested by terrestrial paleobotanical records. 
Data availability. The underlying research data are stored in PANGAEA as datasets PANGAEA.884280, PANGAEA.891294 and PANGAEA.884153, which are combined in PANGAEA.884285 (https://doi.pangaea.de/10.1594/PANGAEA.884285; Grimmer et al., 2018).

Supplement. The supplement related to this article is available online at: https://doi.org/10.5194/cp-14-1739-2018-supplement.

Author contributions. LD and FG conceived the idea; LD, FG, and FL carried out the analyses. FG prepared the manuscript with contributions from all co-authors.

Competing interests. The authors declare that they have no conflict of interest.

Special issue statement. This article is part of the special issue "Global Challenges for our Common Future: a paleoscience perspective" - PAGES Young Scientists Meeting 2017. It is a result of the 3rd Young Scientists Meeting (YSM), Morillo de Tou, Spain, 7-9 May 2017.

Acknowledgements. We thank Carina Hoorn, Jun Tian, Henry Hooghiemstra, Suzette Flantua and an anonymous referee for their insightful comments on the original manuscript. This project was funded by the Deutsche Forschungsgemeinschaft (DFG) through the TROPSAP project (DU221/6) and via the DFG Research Center/Cluster of Excellence "The Ocean in the Earth System - MARUM". The first author thanks GLOMAR - Bremen International Graduate School for Marine Sciences, University of Bremen, Germany, for support. We acknowledge the IODP Gulf Coast Repository (GCR) for their assistance in providing the core samples.

The article processing charges for this open-access publication were covered by the University of Bremen.

Edited by: Yancheng Zhang

Reviewed by: Carina Hoorn, Jun Tian, and one anonymous referee

\section{References}

Anderson, V. J., Saylor, J. E., Shanahan, T. M., and Horton, B. K.: Paleoelevation records from lipid biomarkers: Application to the tropical Andes, Geol. Soc. Am. Bull., 127, 1604-1616, 2015.

Bermúdez, M. A., Hoorn, C., Bernet, M., Carrillo, E., van der Beek, P. A., Garver, J. I., Mora, J. L., and Mehrkian, K.: The detrital record of late-Miocene to Pliocene surface uplift and exhumation of the Venezuelan Andes in the Maracaibo and Barinas foreland basins, Basin Res., 29, 370-395, 2015.

Balslev, H.: Distribution Patterns of Ecuadorean Plant-Species, Taxon, 37, 567-577, 1988.
Barnes, J. B., Ehlers, T. A., Insel, N., McQuarrie, N., and Poulsen, C. J.: Linking orography, climate, and exhumation across the central Andes, Geology, 40, 1135-1138, 2012.

Bartoli, G., Sarnthein, M., Weinelt, M., Erlenkeuser, H., GarbeSchönberg, D., and Lea, D. W.: Final closure of Panama and the onset of northern hemisphere glaciation, Earth Planet. Sc. Lett., 237, 33-44, 2005.

Behling, H., Hooghiemstra, H., and Negret, A. J.: Holocene history of the Choco Rain Forest from Laguna Piusbi, Southern Pacific Lowlands of Colombia, Quaternary Res., 50, 300-308, 1998.

Bendix, A. and Bendix, J.: Heavy rainfall episodes in Ecuador during El Nino events and associated regional atmospheric circulation and SST patterns, Adv. Geosci., 6, 43-49, 2006.

Bendix, J. and Lauer, W.: Die Niederschlagsjahreszeiten in Ecuador und ihre klimadynamische Interpretation, Erdkunde, 46, 118134, 1992.

Billups, K., Ravelo, A. C., Zachos, J. C., and Norris, R. D.: Link between oceanic heat transport, thermohaline circulation, and the Intertropical Convergence Zone in the early Pliocene Atlantic, Geology, 24, 319-322, 1999.

Bush, M. B. and Weng, C.: Introducing a new (freeware) tool for palynology, J. Biogeogr., 34, 377-380, 2007.

Cannariato, K. G. and Ravelo, A. C.: Pliocene-Pleistocene evolution of eastern tropical Pacific surface water circulation and thermocline depth, Paleoceanography, 12, 805-820, 1997.

Colinvaux, P., De Oliveira, P. E., and Moreno Patino, J. E.: Amazon Pollen Manual and Atlas, Harwood Academic Publishers, Amsterdam, 1999.

Coltorti, M. and Ollier, C. D.: Geomorphic and tectonic Evolution of the Ecuadorian Andes, Geomorphology, 32, 1-19, 2000.

Corredor, F.: Eastward extent of the Late Eocene-Early Oligocene onset of deformation across the northern Andes: constraints from the northern portion of the Eastern Cordillera fold belt, Colombia, Journal of South American Earth Sciences, 16, 445-457, 2003.

CPC Merged Analysis of Precipitation: https://www.esrl.noaa.gov/ psd/data/gridded/data.ncep.reanalysis.derived.html, last access: February 2008.

ETOPO1: https://maps.ngdc.noaa.gov/viewers/wcs-client/, last access: June 2018.

Farrell, J. W., Raffi, I., Janecek, T. R., Murray, D. W., Levitan, M., Dadey, K. A., Emeis, K.-C., Lyle, M., Flores, J. A., and Hovan, S.: Late Neogene Sedimentation Patterns in the eastern equatorial Pacific Ocean, Proceedings of the Ocean Drilling Program, Scientific Results, 138, 717-756, 1995.

Fedorov, A. V., Dekens, P. S., McCarthy, M., Ravelo, A. C., deMenocal, P. B., Barreiro, M., Pacanowski, R. C., and Philander, S. G.: The Pliocene paradox (mechanisms for a permanent El Nino), Science, 312, 1485-1489, 2006.

Feng, R. and Poulsen, C. J.: Andean elevation control on tropical Pacific climate and ENSO, Paleoceanography, 29, 795-809, 2014.

Flantua, S., Hooghiemstra, H., Van Boxel, J. H., Cabrera, M., González-Carranza, Z., and González-Arango, C.: Connectivity dynamics since the last glacial maximum in the northern Andes: a pollen-driven framework to assess potential migration, in: $\mathrm{Pa}$ leobotany and Biogeography: A Festschrift for Alan Graham in His 80th Year, edited by: Stevens, W. D., Montiel, O. M., and Raven, P. H., Missouri Botanical Garden Press, St. Louis, 2014. 
Flohn, H.: A hemispheric circulation asymmetry during Late Tertiary, Geologische Rundschau, 70, 725-736, 1981.

Garzione, C. N., Hoke, G. D., Libarkin, J. C., Withers, S., MacFadden, B., Eiler, J., Ghosh, P., and Mulch, A.: Rise of the Andes, Science, 320, 1304-1307, 2008.

Gentry, A. H.: Species richness and floristic composition of Chocó region plant communities, Caldasia, 15, 71-91, 1986.

González, C., Urrego, L. E., and Martínez, J. I.: Late Quaternary vegetation and climate change in the Panama Basin: Palynological evidence from marine cores ODP 677B and TR 163-38, Palaeogeogr. Palaeoclimatol. Palaeoecol., 234, 62-80, 2006.

Govin, A., Holzwarth, U., Heslop, D., Ford Keeling, L., Zabel, M., Mulitza, S., Collins, J. A., and Chiessi, C. M.: Distribution of major elements in Atlantic surface sediments $\left(36^{\circ} \mathrm{N}-49^{\circ} \mathrm{S}\right)$ : Imprint of terrigenous input and continental weathering, Geochem. Geophy. Geosy., 13, 1-23, 2012.

Gregory-Wodzicki, K. M.: Uplift history of the Central and Northern Andes: A review, Geol. Soc. Am. Bull., 112, 1091-1105, 2000.

Grimm, E.: Tilia and Tiliagraph, Illinois State Museum, Springfield, 1991.

Grimmer, F., Dupont, L., Lamy, F., Jung, G., González, C., and Wefer, G.: Supplement to: Grimmer et al. (2018): Early Pliocene vegetation and hydrology changes in western equatorial South America, https://doi.pangaea.de/10.1594/PANGAEA. 884285, 2018.

Groeneveld, J., Hathorne, E. C., Steinke, S., DeBey, H., Mackensen, A., and Tiedemann, R.: Glacial induced closure of the Panamanian Gateway during Marine Isotope Stages (MIS) 95-100, Earth Planet. Sc. Lett., 404, 296-306, 2014.

Haug, G. H. and Tiedemann, R.: Effect of the formation of the Isthmus of Panama on Atlantic Ocean thermohaline circulation, Nature, 393, 673-676, 1998.

Haug, G. H., Tiedemann, R., Zahn, R., and Ravelo, A. C.: Role of Panama uplift on oceanic freshwater balance, Geology, 29, 207210, 2001

Hooghiemstra, H.: Vegetational and Climatic History of the High Plain of Bogotá, Colombia: A Continuous Record of the Last 3.5 Million Years, A.R. Gantner Verlag K.G., Vaduz, 1984.

Hooghiemstra, H., Wijninga, V. M., and Cleef, A. M.: The Paleobotanical Record of Colombia: Implications for Biogeography and Biodiversity, Annals of the Missouri Botanical Garden, 93, 297-325, 2006

Hoorn, C.: Andean tectonics as a cause for changing drainage patterns in Miocene northern South America, Geology, 23, 237240, 1995.

Hoorn, C. and Flantua, S.: An early start for the Panama land bridge, Science, 348, 186-187, 2015.

Hoorn, C., Wesselingh, F. P., ter Steege, H., Bermudez, M. A., Mora, A., Sevink, J., Sanmartin, I., Sanchez-Meseguer, A., Anderson, C. L., Figueiredo, J. P., Jaramillo, C., Riff, D., Negri, F. R., Hooghiemstra, H., Lundberg, J., Stadler, T., Sarkinen, T., and Antonelli, A.: Amazonia through time: Andean uplift, climate change, landscape evolution, and biodiversity, Science, 330, 927-931, 2010.

Hoorn, C., Bogotá-A., G. R., Romero-Baez, M., Lammertsma, E. I., Flantua, S., Dantas, E. L., Dino, R., do Carmo, D. A., and Chemale Jr., F.: The Amazon at sea: Onset and stages of the Amazon River from a marine record, with special reference to
Neogene plant turnover in the drainage basin, Global Planet Change, 153, 51-65, 2017.

Hovan, S. A.: Late Cenozoic Atmospheric Circulation Intensity and climatic history recorded by eolian deposition in the eastern equatorial pacific ocean, Leg 138, Proceedings of the Ocean Drilling Program, Scientific Results, 138, 615-625, 1995.

Jørgensen, P. M. and León-Yánez, S.: Catalogue of the vascular plants of Ecuador $=$ Catálogo de las plantas vasculares del Ecuador, Missouri Botanical Garden Press, St. Louis, Missouri, 1999.

Kaandorp, R. J. G., Wesselingh, F. P., and Vonhof, H. B.: Ecological implications from geochemical records of Miocene Western Amazonian bivalves, J. South Am. Earth Sci., 21, 54-74, 2006.

Kessler, M.: The "Polylepis problem": Where do we stand?, Ecotropica, 8, 97-110, 2002.

Lawrence, K. T., Liu, Z., and Herbert, T. D.: Evolution of the eastern tropical Pacific through Plio-Pleistocene glaciation, Science, 312, 79-83, 2006.

Lisiecki, L. E. and Raymo, M. E.: A Pliocene-Pleistocene stack of 57 globally distributed benthic $\delta^{18} \mathrm{O}$ records, Paleoceanography, 20, 1-17, 2005.

Li, G. and Xie, S. P.: Tropical Biases in CMIP5 Multimodel Ensemble: The Excessive Equatorial Pacific Cold Tongue and Double ITCZ Problems, J. Climate, 27, 1765-1780, 2014.

Luteyn, J. L.: Páramos, Memoirs of The New York Botanical Garden, 1999.

Maher, L. J.: Nomograms for computing 0.95 confidence limits of pollen data, Review of Palaeobotany and Palynology, 13, 85-93, 1972.

Marchant, R., Behling, H., Berrio, J. C., Cleef, A., Duuivenvoorden, J., Hooghiemstra, H., Kuhry, P., Melief, B., Van Geel, B., Van der Hammen, T., Van Reenen, G., and Wille, M.: Mid- to Late-Holocene pollen-based biome reconstructions for Colombia, Quaternary Sci. Rev., 20, 1289-1308, 2001.

Marchant, R., Almeida, L., Behling, H., Berrio, J. C., Bush, M., Cleef, A., Duivenvoorden, J., Kappelle, M., De Oliveira, P., Teixeira de Oliveira-Filho, A., Lozano-Garcia, S., Hooghiemstra, H., Ledru, M.-P., Ludlow-Wiechers, B., Markgraf, V., Mancini, V., Paez, M., Prieto, A., Rangel, O., and Salgado-Labouriau, M.: Distribution and ecology of parent taxa of pollen lodged within the Latin American Pollen Database, Review of Palaeobotany and Palynology, 121, 1-75, 2002.

Milliman, J. D. and Farnsworth, K. L.: River discharge to the coastal ocean: a global synthesis, Cambridge University Press, Cambridge; New York, 2011.

Mix, A., Tiedemann, R., and Blum, P.: Proceedings of the Ocean Drilling Program, Initial Reports, 202, 2003.

Montes, C., Cardona, A., Jaramillo, C., Pardo, A., Silva, J. C., Valencia, V., Ayala, C., Pérez-Angel, L. C., Rondriguez-Parra, L. A., Ramirez, V., and Nino, H.: Middle Miocene closure of the Central American Seaway, Paleoceanography, 348, 226-229, 2015.

Mora, A., Parra, M., Strecker, M. R., Sobel, E. R., Hooghiemstra, H., Torres, V., and Jaramillo, J. V.: Climatic forcing of asymmetric orogenic evolution in the Eastern Cordillera of Colombia, GSA Bulletin, 120, 930-949, 2008.

Mora-Páez, H., Mencin, D. J., Molnar, P., Diederix, H., CardonaPiedrahita, L., Peláez-Gaviria, J.-R., and Corchuelo-Cuervo, Y.: GPS velocities and the construction of the Eastern Cordillera 
of the Colombian Andes, Geophys. Res. Lett., 43, 8407-8416, 2016.

Mulitza, S., Prange, M., Stuut, J. B., Zabel, M., von Dobeneck, T., Itambi, A. C., Nizou, J., Schulz, M., and Wefer, G.: Sahel megadroughts triggered by glacial slowdowns of Atlantic meridional overturning, Paleoceanography, 23, 1-11, 2008.

Murillo, M. T. and Bless, M. J. M.: Spores of recent Colombian Pteridophyta. I. Trilete Spores, Review of Palaeobotany and Palynology, 18, 223-269, 1974.

Murillo, M. T. and Bless, M. J. M.: Spores of recent Colombian Pteridophyta. II. Monolete Spores, Review of Palaeobotany and Palynology, 25, 319-365, 1978.

NCEP reanalysis data provided by the NOAA/OAR/ESRL PSD, B., Colorado, USA, available at: http://www.esrl.noaa.gov/psd/ data/gridded/data.ncep.reanalysis.derived.html, last access: January 2010

Niemann, H., Brunschön, C., and Behling, H.: Vegetation/modern pollen rain relationship along an altitudinal transect between 1920 and 3185 m a.s.l. in the Podocarpus National Park region, southeastern Ecuadorian Andes, Review of Palaeobotany and Palynology, 159, 69-80, 2010.

NODC (Levitus) World Ocean Atlas: http://www.esrl.noaa.gov/psd/ data/gridded/data.nodc.woa94.html, last access: March 2010, 1994.

O’Dea, A., Lessios, A. H., Coates, A. G., Eytan, R. I., RestrepoMoreno, S. A., Cione, A. L., Collins, L. S., de Queiroz, A., Farris, D. W., Norris, R. D., Stallard, R. F., Woodburne, M. O., Aguilera, O., Aubry, M.-P., Berggren, W. A., Budd, A. F., Cozzuol, M. A., Coppard, S. E., Duque-Caro, H., Finnegan, S., Gasparini, G. M., Grossman, E. L., Johnson, K. G., Keigwin, L. D., Knowlton, N., Leigh, E. G., Leonard-Pingel, J. S., Marko, P. B., Pyenson, N. D., Rachello-Dolmen, P. G., Soibelzon, E., Soibelzon, L., Todd, J. A., Vermeij, G. J., and Jackson, J. B. C.: Formation of the Isthmus of Panama, Sci. Adv., 2, 1-11, 2016.

Pak, H. and Zaneveld, J. R.: Equatorial Front in the Eastern Pacific Ocean, J. Phys. Oceanogr., 4, 570-578, 1974.

Pettke, T., Halliday, A. N., and Rea, D. K.: Cenozoic evolution of Asian climate and sources of Pacific seawater $\mathrm{Pb}$ and $\mathrm{Nd}$ derived from eolian dust of sediment core LL44-GPC3, Paleoceanography, 17, 1-13, 2002.

Pisias, N.: Paleoceanography of the eastern equatorial Pacific during the Neogene: Synthesis of Leg 138 drilling results, Proceedings of the Ocean Drilling Program, Scientific Results, 138, 521, 1995.

Ravelo, A. C., Andreasen, D. H., Lyle, M. W., Lyle, A. O., and Wara, M. W.: Regional climate shifts caused by gradual global cooling in the Pliocene epoch, Nature, 429, 263-267, 2004.

Regal, P. J.: Pollination by Wind and Animals: Ecology of Geographic Patterns, Annual Review of Ecology and Systematics, 13, 497-524, 1982.

Richter, T. O., van der Gaast, S., Koster, B., Vaars, A., Gieles, R., de Stigter, H. C., de Haas, H., and van Weering, T. C. E.: The Avaatech XRF Core Scanner: Technical description and applications to NE Atlantic sediments, in: New Techniques in Sediment Core Analysis, edited by: Rothwell, R. G., Geological Society, London, Special Publications, 2006.

Rincón-Martínez, D.: Eastern Pacific background state and tropical South American climate history during the last 3 million years,
2013, Fachbereich Geowissenschaften, Universität Bremen, Bremen, 2013.

Rincón-Martínez, D., Lamy, F., Contreras, S., Leduc, G., Bard, E., Saukel, C., Blanz, T., Mackensen, A., and Tiedemann, R.: More humid interglacials in Ecuador during the past $500 \mathrm{kyr}$ linked to latitudinal shifts of the equatorial front and the Intertropical Convergence Zone in the eastern tropical Pacific, Paleoceanography, 25, 1-15, 2010.

Rodbell, D. T., Seltzer, G. O., Anderson, D. M., Abbott, M. B., Enfield, D. B., and Newman, J. H.: An 15,000-year record of El Nino-driven alluviation in southwestern Ecuador, Science, 283 516-520, 1999.

Roubik, D. W. and Moreno P., J. E.: Pollen and spores of Barro Colorado Island (Panama), Missouri Botanical Garden, St. Louis, MO, 1991.

Salzmann, U., Williams, M., Haywood, A. M., Johnson, A. L. A., Kender, S., and Zalasiewicz, J.: Climate and environment of a Pliocene warm world, Palaeogeography, Palaeoclimatology, Palaeoecology, 309, 1-8, 2011.

Sánchez-Baracaldo, P.: Phylogenetics and biogeography of the neotropical fern genera Jamesonia and Eriosorus (Pteridaceae), Am. J. Bot., 91, 274-284, 2004.

Schneider, T., Bischoff, T., and Haug, G. H.: Migrations and dynamics of the intertropical convergence zone, Nature, 513, 4553, 2014.

Seilles, B., Goni, M. F. S., Ledru, M. P., Urrego, D. H., Martinez, P., Hanquiez, V., and Schneider, R.: Holocene land-sea climatic links on the equatorial Pacific coast (Bay of Guayaquil, Ecuador), The Holocene, 26, 567-577, 2016.

Sklenár, P. and Jorgensen, P. M.: Distribution patterns of Páramo Plants in Ecuador, J. Biogeogr., 26, 681-691, 1999.

Sklenár, P., Dusková, E., and Balslev, H.: Tropical and Temperate: Evolutionary History of Páramo Flora, Bot. Rev., 77, 71-108, 2011.

Spikings, R. A., Winkler, W., Hughes, R. A., and Handler, R.: Thermochronology of allochthonous terranes in Ecuador: Unravelling the accretionary and post-accretionary history of the Northern Andes, Tectonophysics, 399, 195-220, 2005.

Steph, S.: Pliocene stratigraphy and the impact of Panama uplift on changes in Caribbean and tropical east Pacific upper ocean stratification, 2005. Mathematisch-Naturwissenschaftliche Fakultät, Christian-Albrechts-Universität Kiel, Kiel, 2005.

Steph, S., Tiedemann, R., Groeneveld, J., Sturm, A., and Nürnberg, D.: Pliocene Changes in Tropical East Pacific Upper Ocean Stratification: Response to Tropical Gateways?, Proceedings of the Ocean Drilling Program, Scientific Results, 202, 2006a.

Steph, S., Tiedemann, R., Prange, M., Groeneveld, J., Nurnberg, D., Reuning, L., Schulz, M., and Haug, G. H.: Changes in Caribbean surface hydrography during the Pliocene shoaling of the Central American Seaway, Paleoceanography, 21, 1-25, $2006 \mathrm{~b}$.

Steph, S., Tiedemann, R., Prange, M., Groeneveld, J., Schulz, M., Timmermann, A., Nürnberg, D., Rühlemann, C., Saukel, C., and Haug, G. H.: Early Pliocene increase in thermohaline overturning: A precondition for the development of the modern equatorial Pacific cold tongue, Paleoceanography, 25, 1-17, 2010.

Takahashi, K. and Battisti, D. S.: Processes Controlling the Mean Tropical Pacific Precipitation Pattern. Part I: The Andes and the Eastern Pacific ITCZ, J. Climate, 20, 3434-3451, 2007. 
Tiedemann, R., Sturm, A., Steph, S., Lund, S. P., and Stoner, J. S.: Astronomically calibrated timescales from 6 to $2.5 \mathrm{Ma}$ and benthic isotope stratigraphies, sites 1236, 1237, 1239, and 1241, Proceedings of the Ocean Drilling Program, Scientific Results, 202, 2007.

Tjallingii, R., Röhl, U., Kölling, M., and Bickert, T.: Influence of the water content on X-ray fluorescence core-scanning measurements in soft marine sediments, Geochem. Geophys. Geosy., 8, 1-12, 2007.

Twilley, R. R., Cárdenas, W., Rivera-Monroy, V. H., Espinoza, J., Suescum, R., Armijos, M. M., and Solórzano, L.: The Gulf of Guayaquil and the Guayas River Estuary, Ecuador, in: Coastal Marine Ecosystems of Latin America, edited by: Seeliger, U. and Kjerfve, B., Springer, Heidelberg, 2001.

Van der Hammen, T.: The Pleistocene Changes of Vegetation and Climate in Tropical South America, J. Biogeogr., 1, 3-26, 1974.

Van der Hammen, T., Werner, J. H., and van Dommelen, H.: Palynological record of the upheaval of the Northern Andes: a study of the Pliocene and Lower Quaternary of the Colombian early evolution of its high-Andean biota, Review of Palaeobotany and Palynology, 16, 1-122, 1973.

Vuille, M., Bradley, R. S., and Keimig, F.: Climate variability in the Andes of Ecuador and its relation to tropical Pacific and Atlantic Sea surface temperature anomalies, J. Climate, 13, 2520-2535, 2000 .
Wara, M. W., Ravelo, A. C., and Delaney, M. L.: Permanent El Nino-like conditions during the Pliocene warm period, Science, 309, 758-761, 2005.

Wijninga, V. M.: A Pliocene Podocarpus forest mire from the area of the high plain of Bogotá (Cordillera Oriental, Colombia), Rev. Palaeobot. Palyno., 92, 157-205, 1996.

Wijninga, V. M. and Kuhry, P.: A Pliocene Flora from the Subachoque Valley (Cordillera Oriental, Colombia), Rev. Palaeobot. Palyno., 62, 249-290, 1990.

World Wildlife Fund (WWF): https://www.worldwildlife.org/ ecoregions/, last access: October 2017.

Zhang, X., Prange, M., Steph, S., Butzin, M., Krebs, U., Lunt, D. J., Nisancioglu, K. H., Park, W., Schmittner, A., Schneider, B., and Schulz, M.: Changes in equatorial Pacific thermocline depth in response to Panamanian seaway closure: Insights from a multimodel study, Earth Planet. Sc. Lett., 317/318, 76-84, 2012.

Zhang, Y. G., Pagani, M., and Liu, Z.: A 12-million-year temperature history of the tropical Pacific Ocean, Science, 344, 84-87, 2014. 